\title{
Effect of vegetation biomass structure on thermal performance of tropical green roof
}

\author{
C. Y. Jim
}

Received: 4 September 2010/Revised: 15 April 2011/Accepted: 19 April 2011/Published online: 7 May 2011

(C) The Author(s) 2011. This article is published with open access at Springerlink.com

\begin{abstract}
The passive cooling effect of green roofs in humid, tropical Hong Kong was investigated with reference to three vegetated plots, grass, groundcover herb, and shrub, with contrasting growth form and biomass structure and a bare control plot. Temperature was monitored at 15-min intervals for a year at seven levels: high $(\mathrm{H})$ at $200 \mathrm{~cm}$, middle (M) at $60 \mathrm{~cm}$, low (L) at $20 \mathrm{~cm}$, surface, soil, rockwool (water storage), and roof-tile surface. The findings indicated the crucial roles played by biomass quantity and structural complexity in passive cooling functions. Temperature variations of vegetated roofs occurred mainly during the day, with lower maximum and minimum than the control, but they did not cool air at night better than the control. Control and grass surfaces were warmed above the ambient temperature, but groundcover and shrub surfaces followed the ambient. Despite complex biomass structure, shrub created the most extreme diurnal air temperature regime. Despite simple biomass structure, grass cooled air more effectively than groundcover and shrub. Four anomalies in the vertical temperature profile were detected. First, the grass roof cooled daytime nearground air to create a suspended temperature inversion. Second, the stagnant air within the shrub biomass trapped heat to generate a daytime canopy temperature inversion. Third, the elevated branch-foliage biomass of groundcover and shrub brought passive cooling to form a perched thermal discontinuity. Fourth, the air gap of the plastic drainage layer arrested downward heat transmission in all vegetated plots to form a subsurface thermal discontinuity.
\end{abstract}

C. Y. Jim $(\bowtie)$

Department of Geography, University of Hong Kong,

Pokfulam Road, Hong Kong, China

e-mail: hragjcy@hkucc.hku.hk
The findings provide hints on species choice and design of green roofs.

Keywords Passive cooling - Vertical temperature profile $\cdot$ Suspended temperature inversion - Canopy temperature inversion - Perched thermal discontinuity . Subsurface thermal discontinuity

\section{Introduction}

As an exceptionally compact city filled pervasively with high-rise buildings and roads, urban Hong Kong has few green spaces. Inadequate street-level open spaces could be partly compensated for by elevated solution spaces on buildings. Numerous bare flat roof tops are rarely vegetated and enlisted for amenity purpose. Green roofs are seldom established in the humid, subtropical city with 7 million people sharing merely $20 \mathrm{~km}^{2}$ of urban open spaces. A green-roof movement, launched in 2006, encourages installation of ecologically sound vegetated cover on buildings (Jim 2008). Scientific studies on the microclimatic effect and thermal performance of green roofs could promote their adoption. The high-population-density city with excessive impervious surfaces suffers from an increasingly acute urban heat-island effect (Bass et al. 2002; Sailor 2006; EPA 2009a). The heat retention capacity of the urban fabric could be ameliorated by vegetation supplemented by green roofs (Bass et al. 2003; EPA 2009b). Passive cooling due to latent heat extraction has been widely recognized as a key benefit of urban green spaces (Taha et al. 1991; Köhler 2004; Shin and Lee 2005; Chang et al. 2007; Lee et al. 2009) and green roofs (Takakura et al. 2000; Liu 2003; Wong et al. 2003). The energysaving potentials (Akbari and Konopaci 2005) has been 
strongly advocated as the economic-environmental justification for roof greening. The above-ground green spaces could also relieve the scarcity of open spaces in compact cities (Banting et al. 2005). Green roofs could permit the mixing and integration of green spaces to enhance the quality of nature in cities (Yokohari and Amati 2005).

Based on mathematical modeling or empirical analysis, many studies have been conducted on green roofs outside the tropics. Little field data exist to ascertain the nature and magnitude of passive cooling in the tropics. A research green roof could yield objective data on environmental benefits and serve as a demonstration site. Most thermal performance studies of green roofs focused on air temperature above the ground, plus some measurements of soil and indoor temperature below the roof. Few studies evaluated the passive cooling effect by monitoring temperature in the entire vertical profile at different levels, including air at various heights, vegetation surface, and individual layers in the substrate. Moreover, comparing the thermal performance of different vegetation types has received little attention.

This field-based study in humid, tropical Hong Kong evaluated green roofs of three vegetation types with different growth forms and biomass structure in comparison with a control plot. The passive cooling effect of green roofs was investigated with respect to diurnal temperature variations across the vertical profile. As the first green-roof research in the city, the study could provide practical experience on extensive green-roof establishment and maintenance using different vegetation types. The findings could also provide a scientific basis to support the greenroof movement in tropical cities in this region and beyond.

\section{Study area and methods}

The green-roof experiment was conducted in Hong Kong, which is located in the warm and humid subtropical climate zone at latitude $22^{\circ} \mathrm{N}$ at the coast of south China and on the southern edge of the Tropic of Cancer. The weather is dominated by the monsoon macroclimatic system. The mean monthly temperature for the warm, wet summer months ranges from 27.9 to $28.7^{\circ} \mathrm{C}$, and for the cool, dry winter months from 16.1 to $17.8^{\circ} \mathrm{C}$. Annual rainfall reaches $2,383 \mathrm{~mm}$, with $84.4 \%$ dropped in the wet season that runs from April to September. The experimental site is situated in the main campus of the University of Hong Kong, which is located in the foothills portion of the Western District on Hong Kong Island at the fringe of the continuously built-up urban area. The building density in the campus and its adjacent neighborhood, composed mainly of residential and institutional land uses, is described as medium, with average site coverage at the ground level of usually $100 \%$ for residential sites and about $65 \%$ for institutional ones. Building height reaches around 20 stories for residential blocks and six for institutional ones. The roads are all narrow with only two carriageways.

On the flat roof of the four-storey Runme Shaw Building, University of Hong Kong, an extensive green roof was retrofitted in June 2006. Covering $256 \mathrm{~m}^{2}$, the site was divided into four equal square plots each measuring $8 \mathrm{~m} \times 8 \mathrm{~m}$ (Figs. 1, 2): (1) control plot with the original bare roof covered by concrete tiles; three experimental plots planted with (2) turfgrass (Zoysia tenuifolia Willd. ex Thiele, Korean Velvet Grass), (3) groundcover vine (Arachis pintoi Krapov. \& W.C. Greg., Perennial Peanut), a scandent flowering herb, and (4) shrub (Duranta repens L., Golden Dewdrops). The grass was established by sods, the groundcover with stem cuttings, and the shrub with young plants. It took about a year's growth to form a complete and vigorous plant cover. Weeding, organic fertilizers, and mowing were conducted regularly. The shrub was pruned

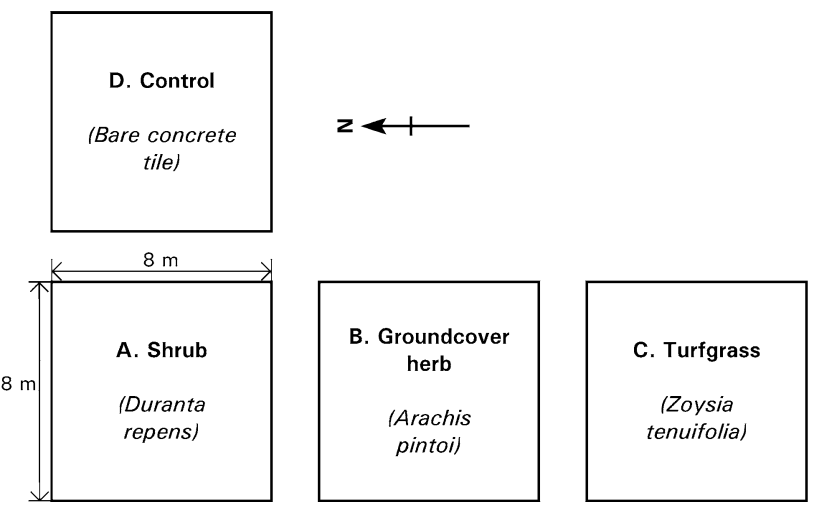

Fig. 1 Demarcation of the green-roof research site at the University of Hong Kong showing the layout of the three experimental plots $(A$, $B$ and $C$ ) each measuring $8 \mathrm{~m} \times 8 \mathrm{~m}$, and the control plot $(D)$

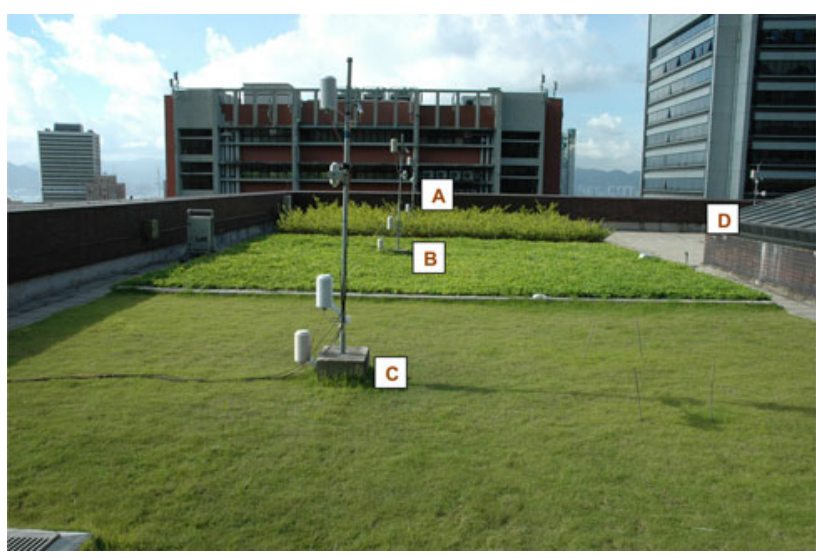

Fig. 2 Three experimental plots $(A, B, C)$ and the control plot $(D)$ at the University of Hong Kong green-roof research site, with the environmental sensor stations located at the center of each plot 
once per year to $70 \mathrm{~cm}$ tall, and the turfgrass was mown on average once every 2 months. For the groundcover, the occasional stems that spread beyond the plot boundary or assumed an ascending habit were cut on average once every 2 months. The site is well exposed with a high skyview factor (SKV), allowing almost unobstructed solar access and energy dissipation by outgoing terrestrial radiation.

The waterproof membrane, thermal insulation, and concrete tiles of the rooftop, renovated shortly before green-roof installation, were kept undisturbed. The multiple layers of the green roof were laid on the concrete tiles (Table 1; Fig. 3) using proprietary materials (Nophadrain, Kirkrade, The Netherlands). It began with a root barrier at the bottom, followed by a 2.5 -cm-thick dimple-type composite plastic drain layer, manufactured with a geotextile filter glued on the upper side and a protection geotextile sheet on the lower. It was then covered by a 4-cm-thick water-storage layer made of hydrophilic rokwool (compressed silica fibers) boards. A soil mix composed of completely decomposed granite mixed with mature compost was spread on the surface. The thermal conductivity and specific heat of the three main layers of green-roof materials are summarized in Table 2.

Soil thickness was adjusted according to the differential rooting needs of the three vegetation types, namely, $3.5 \mathrm{~cm}$ for grass, $5 \mathrm{~cm}$ for groundcover, and $8 \mathrm{~cm}$ for shrub (Table 1). The green-roof system has a maximum saturated weight of 126,159 , and $231 \mathrm{~kg} / \mathrm{m}^{2}$, respectively, for the three vegetation types. The study attempted to find the minimum green-roof weight to retrofit existing flat roofs, which in Hong Kong commonly have a limited loadbearing capacity of around 1.5-3.0 kPa $\left(150-300 \mathrm{~kg} / \mathrm{m}^{2}\right)$. The rockwool layer partly substitutes the water-storage function to keep soil thickness to the minimum. A timercontrolled automatic sprinkler irrigation system was

Table 1 Built-up height and weight of the three extensive green roofs with different vegetation types

\begin{tabular}{|c|c|c|c|c|c|c|}
\hline \multirow[t]{2}{*}{ Green-roof layer } & \multicolumn{2}{|l|}{ Turfgrass } & \multicolumn{2}{|c|}{ Groundcover } & \multicolumn{2}{|l|}{ Shrub } \\
\hline & $\begin{array}{l}\text { Thickness } \\
(\mathrm{mm})\end{array}$ & $\begin{array}{l}\text { Saturated weight } \\
\left(\mathrm{kg} / \mathrm{m}^{2}\right)\end{array}$ & $\begin{array}{l}\text { Thickness } \\
(\mathrm{mm})\end{array}$ & $\begin{array}{l}\text { Saturated weight } \\
\left(\mathrm{kg} / \mathrm{m}^{2}\right)\end{array}$ & $\begin{array}{l}\text { Thickness } \\
(\mathrm{mm})\end{array}$ & $\begin{array}{l}\text { Saturated weight } \\
\left(\mathrm{kg} / \mathrm{m}^{2}\right)\end{array}$ \\
\hline Nophadrain WSB80 root barrier & 0.5 & 0.5 & 0.5 & 0.5 & 0.5 & 0.5 \\
\hline Nophadrain ND5 +1 drainage composite & 25 & 4.5 & 25 & 4.5 & 25 & 4.5 \\
\hline Nophadrain WSM50 water reservoir panel & 50 & 46 & 50 & 46 & 50 & 46 \\
\hline Soil layer (decomposed granite and compost) & 35 & 70 & 50 & 100 & 80 & 160 \\
\hline Vegetation layer (estimate) & & 5 & & 8 & & 20 \\
\hline Total & 110.5 & 126 & 125.5 & 159 & 155.5 & 231 \\
\hline
\end{tabular}

Fig. 3 Cross-section of the experimental green roof adopted in the study showing the fivelayer light-weight design using proprietary materials. The extensive green roof was retrofitted on an existing University of Hong Kong academic building with roofslab construction details following the local architectural standard. The thickness of the growth medium (soil) varies according to vegetation type, as given in Table 1

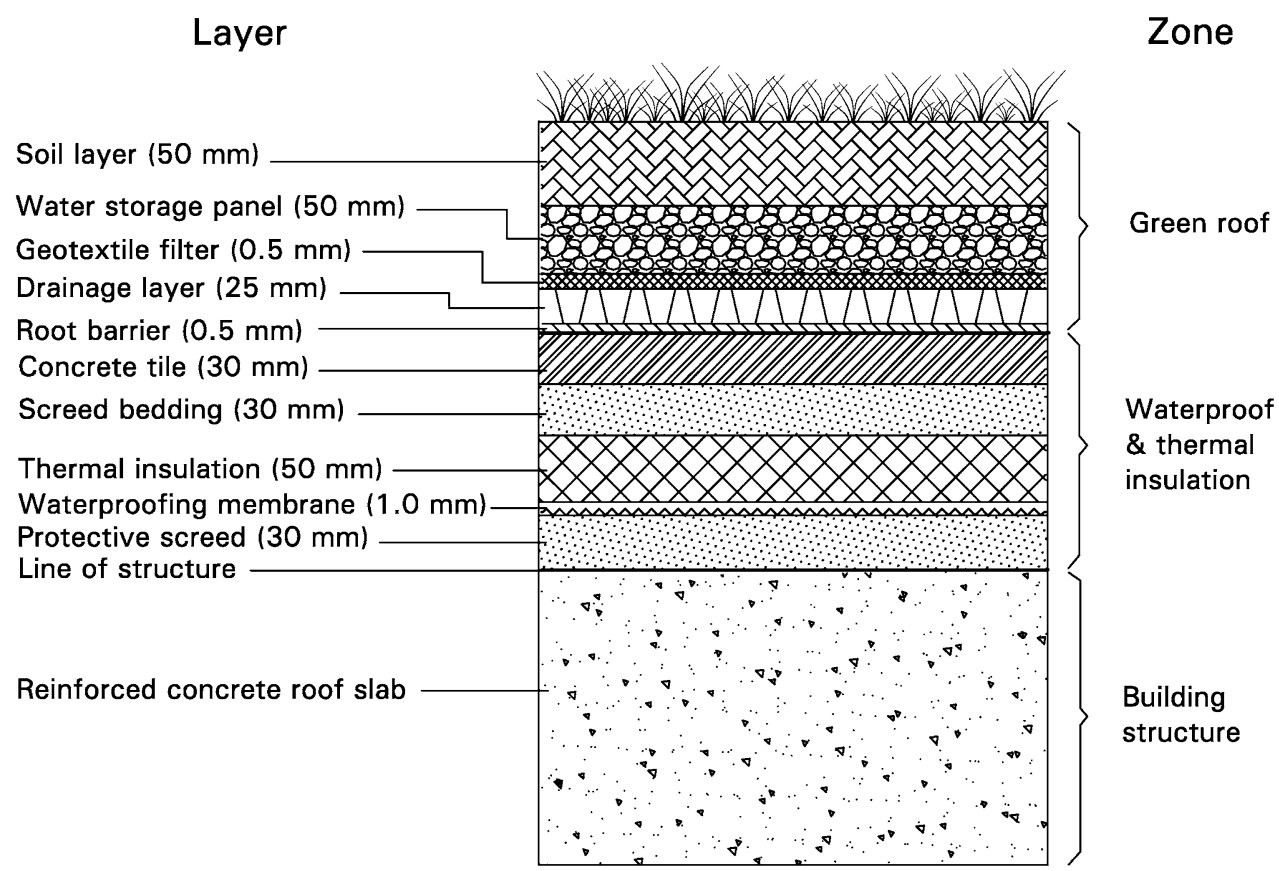


Table 2 Thermal conductivity and specific heat of the green-roof materials

\begin{tabular}{|c|c|c|c|c|c|c|}
\hline \multirow[t]{2}{*}{ Water content $\left(\mathrm{m}^{3} \mathrm{~m}^{-3}\right)$} & \multicolumn{3}{|c|}{ Thermal conductivity $[\mathrm{W} /(\mathrm{mK})]$} & \multicolumn{3}{|c|}{ Specific heat $[\mathrm{kJ} /(\mathrm{kgK})]$} \\
\hline & Soil $^{\mathrm{a}}$ & Rockwool $^{\text {b }}$ & Drainage $^{c}$ & Soil $^{\mathrm{a}}$ & Rockwool $^{\text {b }}$ & Drainage $^{c}$ \\
\hline 0.4 & 6.16 & 9.380 & & 2.54 & 1.68 & \\
\hline 0.3 & 3.34 & 9.379 & & 2.27 & 1.26 & \\
\hline 0.2 & 1.41 & 9.378 & & 1.99 & 0.85 & \\
\hline 0.1 & 0.32 & 9.378 & & 1.72 & 0.43 & \\
\hline 0.0 & & & 0.0255 & & & 1.00 \\
\hline
\end{tabular}

${ }^{a}$ Sandy loam soil with water-holding capacity at $0.43 \mathrm{~m}^{3} \mathrm{~m}^{-3}$

b Water-holding capacity at $0.60 \mathrm{~m}^{3} \mathrm{~m}^{-3}$

c Thermal properties of the drainage layer is reckoned at $300 \mathrm{~K}$ and free of water accumulation

installed, with an impact-type sprinkler head (Rain Bird, Azusa, CA, USA) installed at the corner of every vegetated plot. The control plot was not irrigated. A rainfall detector was included to turn off the water supply when $10 \mathrm{~mm}$ of antecedent rainfall has accumulated in its receptacle. Irrigation is essential in the dry season from October to March. In the rainy season, supplementary watering could improve plant performance during extended dry spells between rainfall events. If applicable, irrigation was turned on twice per day, at 0900-0930 $\mathrm{h}$ and 2100-2130 $\mathrm{h}$.

Sensors for continual temperature monitoring were installed at the center of each square plot on a pole anchored by concrete ballast. The influence of advection on adjacent plots was minimized by the relatively large size of individual plots $(8 \mathrm{~m} \times 8 \mathrm{~m})$, the placement of the sensors at the plot center, the widely open and exposed site, and the long-term composite average approach adopted in data analysis. They included: (1) three thermister-type air-temperature sensors with radiation shields, with range -30 to $70^{\circ} \mathrm{C}$ and accuracy $\pm 0.2^{\circ} \mathrm{C}$ (external temperature sensor 8160TFF, Lufft, Fellbach, Germany) at 20, 60, and $200 \mathrm{~cm}$ levels; (2) a weatherproof infrared radiometer with accuracy within $\pm 0.2^{\circ} \mathrm{C}$ (infrared radiometer SI-111, Apogee, Logan, UT, USA) to detect surface temperature of the bare tile at the control plot and of foliage surface at the vegetated plots; and (3) three thermister-type soil temperature sensors (external temperature sensor 8160TFF, Lufft, Fellbach, Germany) buried in the middle of the soil and rockwool layers and placed on the tile surface below the root barrier. The infrared sensors were mounted at $1.5 \mathrm{~m}$ above the ground, pointing $45^{\circ}$ toward the ground, with an elliptical target area of about $0.42 \mathrm{~m}^{2}$. A weather station (Onset Hobo, Pocasset, MA, USA) was installed near the plots to glean a comprehensive range of the rooftop microclimatic data. All sensors were synchronized to take readings at 15 -min interval, and data were stored in loggers (Datalogger 8160, Lufft) kept in a weatherproof cabinet. Based on 2009 data, running from 1 January to 31 December 2009, annual average temperature for the 24-h daily period was computed using SPSSPC version 17 and Microsoft Excel. The composite average approach was adopted in the data analysis to provide a synoptic summary of temperature variations by experimental plots and sensor positions.

The experimental site is situated on the roof of a lowrise building about $16 \mathrm{~m}$ tall, which falls well below the 60-m urban canopy layer in the core urban area of Hong Kong where the study area is situated ( $\mathrm{Ng}$ et al. 2011). The wind condition in the dense and high-rise city area, based on government meteorological data, is notably suppressed due to poor site porosity and limited urban ventilation. The mean wind speed measured at built-up locations at $7.9-9.1 \mathrm{~km} / \mathrm{h}$ is about one third of that recorded at open areas at $25.7-26.7 \mathrm{~km} / \mathrm{h}$ (Hong Kong Observatory 2005). Selected temperature parameters on a typical summer day are plotted in Fig. 4 for comparison with average annual data. Diurnal temperature changes of the sample day with reference to control and experimental plots demonstrate patterns that are analogous to annual averages. Key findings are summarized in Table 3.

\section{Results and discussion}

Air temperature above the control roof

The control site exemplifies the general air temperature scenario on flat bare roofs that are common in Hong Kong and other tropical cities (Fig. 5; Table 3). The three measurement heights, 20, 60, and $200 \mathrm{~cm}$ above ground, are labeled respectively as low $(\mathrm{L})$, middle $(\mathrm{M})$, and high $(\mathrm{H})$. Starting from midnight, the air temperature begins to drop slowly, reaching the daily minimum of $21.5^{\circ} \mathrm{C}$ at $0630 \mathrm{~h}$. Thereafter, it rises rather quickly to reach the maximum of $27^{\circ} \mathrm{C}$ at $1500 \mathrm{~h}$. It then drops quickly to $23.4^{\circ} \mathrm{C}$ at $1930 \mathrm{~h}$, and cools at a slow and rather constant rate of about $0.15^{\circ} \mathrm{C} / \mathrm{h}$ throughout the night. The occurrence of maximum and minimum temperature for $\mathrm{L}, \mathrm{M}$, and $\mathrm{H}$ is 

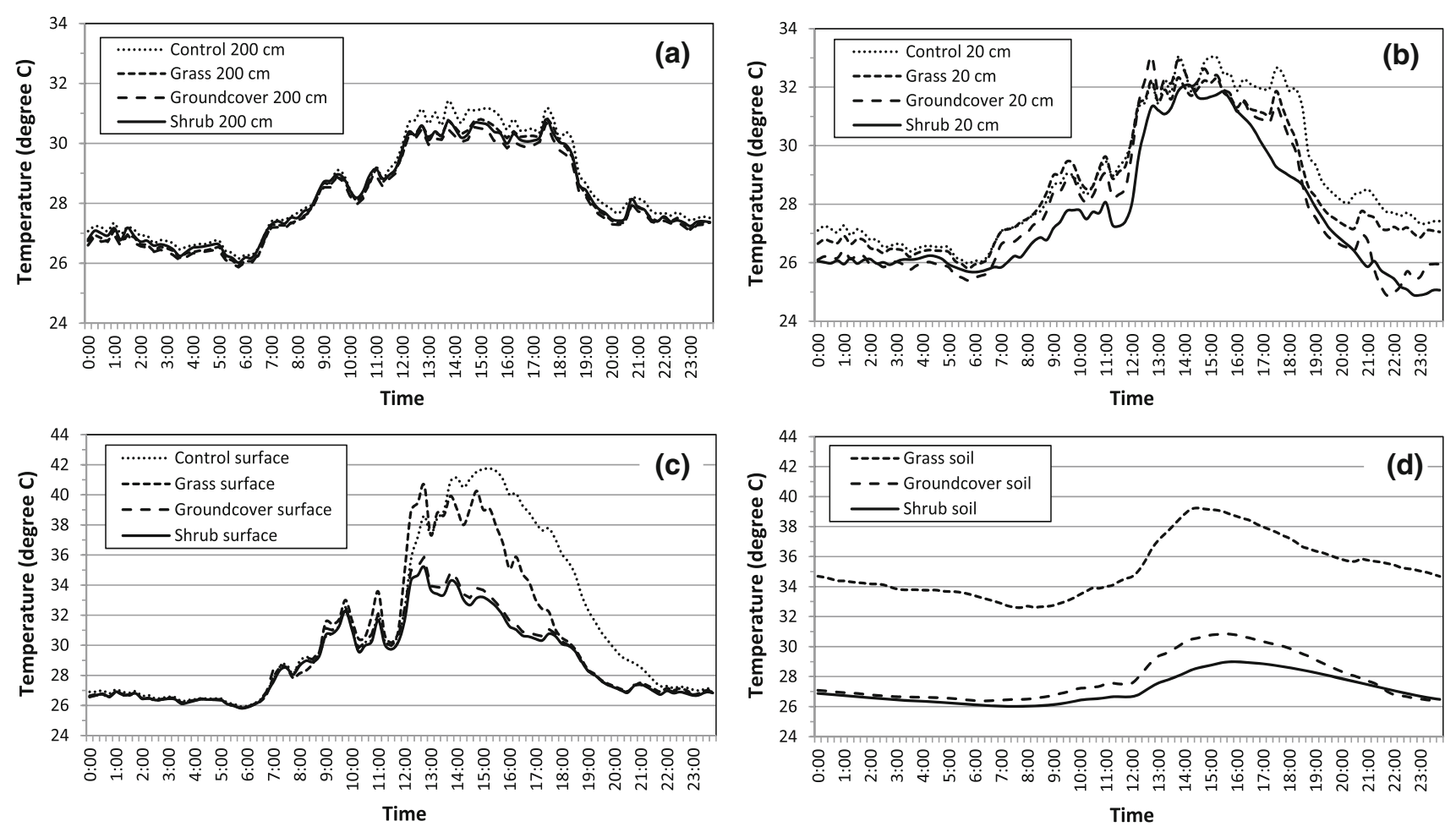

Fig. 4 Diurnal temperature patterns on a typical sunny summer day (4 July 2009) for the control and the three green-roof plots: a air temperature at $200 \mathrm{~cm}$ high, $\mathbf{b}$ air temperature at $20 \mathrm{~cm}$ high, $\mathbf{c}$ infrared surface temperature, and $\mathbf{d}$ soil temperature

synchronous. The effect of the heated roof surface on air temperature occurs with a delay of about $3 \mathrm{~h}$ after peak radiation at noon. The daily air temperature pattern follows an extended bell shape, peaking at around $1430 \mathrm{~h}$.

The air temperature decreases notably with height during the day and the reverse is true with a gentle gradient during the night to display a subdued temperature inversion adjacent to the tile-air interface at $\mathrm{L}$. At $\mathrm{M}$ and $\mathrm{H}$, the temperature is similar throughout the $24-\mathrm{h}$ cycle, except that $\mathrm{M}$ is slightly hotter by $0.2^{\circ} \mathrm{C}$ around $1500 \mathrm{~h}$. The $\mathrm{L}$ curve deviates evidently from those of $\mathrm{M}$ and $\mathrm{H}$, especially during the day. From dusk to midnight, the temperature at the three levels nearly converges. From midnight to dawn, however, the roof surface cools progressively at L more than at $\mathrm{M}$ and $\mathrm{H}$ by a small margin. The highest daytime temperature occurs at $\mathrm{L}$, with notably cooler $\mathrm{M}$ and $\mathrm{H}$, indicating strong warming from below. The highest nighttime temperature occurs at $\mathrm{M}$ and $\mathrm{H}$, with slightly cooler $\mathrm{L}$, indicating cooling from below. The temperature amplitude is markedly wider during the day (about $1.25^{\circ} \mathrm{C}$ ) than at night $\left(0.25^{\circ} \mathrm{C}\right)$. The near-ground air is warmed principally by convective sensible heat transfer with a clear height-decay function. Warming from below imposes more effect on near-ground air layer than that above it. The heat transfer from the bare roof surface to air is conspicuously confined to the near-ground air layer. At night, the longwave radiative ground cooling and its effect on air temperature is less affected by the height-decay function. Cooling from below affects all air layers, with marginally more impact on near-ground air.

Air temperature above the grass roof

The effect of the grass roof on air temperature is compared with the control (bare roof) at the same three levels (Fig. 6; Table 3). The air temperature is notably lowered by vegetative cooling (Taha et al. 1991; Wong et al. 2003). The most prominent difference is shown by the $\mathrm{H}$ curve, which maintains its temperature above $\mathrm{M}$ and $\mathrm{L}$ throughout the 24-h period. Thus, the temperature inversion persists in both day and night. For comparison, at the control site, the air temperature at $\mathrm{L}$ is warmer than $\mathrm{M}$ and $\mathrm{H}$ during the day, and a reverse pattern with temperature inversion occurs only at night.

The second major feature is that the temperature difference between $\mathrm{L}, \mathrm{M}$, and $\mathrm{H}$ is narrower during the day than at night, a pattern that contrasts with the control. Thus, during the day, the temperature at different heights varies within a confined range of $0.4^{\circ} \mathrm{C}$, increasing to $1.0^{\circ} \mathrm{C}$ during the night. The grass generates a similar microclimate at different heights during the day. The small depression at $0930 \mathrm{~h}$ is due to sprinkler irrigation, which spreads water droplets to lower the air temperature. Each morning, the plots are watered at a rate equivalent to 
Table 3 Summary of vertical temperature profile of control and green-roof plots

\begin{tabular}{|c|c|c|c|c|c|c|}
\hline \multirow[t]{2}{*}{ Vegetation and height } & \multicolumn{2}{|l|}{ Minimum } & \multicolumn{2}{|l|}{ Maximum } & \multicolumn{2}{|l|}{ Range $^{\mathrm{a}}$} \\
\hline & Time (hours) & Temperature $\left({ }^{\circ} \mathrm{C}\right)$ & Time (hours) & Temperature $\left({ }^{\circ} \mathrm{C}\right)$ & Interval $^{\mathrm{b}}$ & Amplitude $\left({ }^{\circ} \mathrm{C}\right)$ \\
\hline \multicolumn{7}{|l|}{ Control } \\
\hline Air $200 \mathrm{~cm}$ & 0615 & 21.8 & 1445 & 25.7 & $8 \mathrm{~h} 30 \mathrm{~min}$ & 3.9 \\
\hline Air $60 \mathrm{~cm}$ & 0615 & 21.8 & 1445 & 25.9 & 8 h $30 \mathrm{~min}$ & 4.1 \\
\hline Air $20 \mathrm{~cm}$ & 0615 & 21.5 & 1500 & 27.0 & $8 \mathrm{~h} 45 \mathrm{~min}$ & 5.5 \\
\hline Surface $^{c}$ & 0615 & 21.3 & 1430 & 33.4 & $8 \mathrm{~h} 15 \mathrm{~min}$ & 12.1 \\
\hline \multicolumn{7}{|l|}{ Grass } \\
\hline Air $200 \mathrm{~cm}$ & 0615 & 21.6 & 1415 & 25.3 & $8 \mathrm{~h}$ & 3.7 \\
\hline Air $60 \mathrm{~cm}$ & 0615 & 20.8 & 1415 & 24.9 & $8 \mathrm{~h}$ & 4.1 \\
\hline Air $20 \mathrm{~cm}$ & 0615 & 20.6 & 1415 & 25.3 & $8 \mathrm{~h}$ & 4.7 \\
\hline Surface $^{c}$ & 0630 & 21.4 & 1330 & 30.2 & $7 \mathrm{~h}$ & 8.8 \\
\hline Soil & 0815 & 25.9 & 1500 & 30.9 & $6 \mathrm{~h} 45 \mathrm{~min}$ & 5.0 \\
\hline Rockwool & 0845 & 23.3 & 1615 & 27.3 & $7 \mathrm{~h} 30 \mathrm{~min}$ & 4.0 \\
\hline Tile & 0900 & 21.8 & 2230 & 23.5 & $13 \mathrm{~h} 30 \mathrm{~min}$ & 1.7 \\
\hline \multicolumn{7}{|l|}{ Groundcover } \\
\hline Air $200 \mathrm{~cm}$ & 0615 & 21.5 & 1415 & 25.1 & $8 \mathrm{~h}$ & 3.6 \\
\hline Air $60 \mathrm{~cm}$ & 0615 & 21.3 & 1415 & 25.4 & $8 \mathrm{~h}$ & 4.1 \\
\hline Air $20 \mathrm{~cm}$ & 0615 & 20.8 & 1415 & 26.4 & $8 \mathrm{~h}$ & 5.6 \\
\hline Surface $^{c}$ & 0630 & 21.2 & 1300 & 28.1 & $6 \mathrm{~h} 30 \mathrm{~min}$ & 6.9 \\
\hline Soil & 0715 & 20.8 & 1500 & 24.9 & 7 h $45 \min$ & 4.1 \\
\hline Rockwool & 0815 & 21.3 & 1615 & 24.5 & $8 \mathrm{~h}$ & 3.2 \\
\hline Tile & 1115 & 22.2 & 2000 & 23.2 & 8 h 45 min & 1.0 \\
\hline \multicolumn{7}{|l|}{ Shrub } \\
\hline Air $200 \mathrm{~cm}$ & 0615 & 21.6 & 1415 & 25.3 & $8 \mathrm{~h}$ & 3.7 \\
\hline Air $60 \mathrm{~cm}$ & 0615 & 21.1 & 1415 & 26.2 & $8 \mathrm{~h}$ & 5.1 \\
\hline Air $20 \mathrm{~cm}$ & 0630 & 20.3 & 1415 & 25.7 & 7 h 45 min & 5.4 \\
\hline Surface $^{c}$ & 0630 & 21.3 & 1315 & 28.1 & $6 \mathrm{~h} 45 \mathrm{~min}$ & 6.8 \\
\hline Soil & 0745 & 21.2 & 1545 & 23.8 & $8 \mathrm{~h}$ & 2.6 \\
\hline Rockwool & 0930 & 21.6 & 1730 & 23.5 & $8 \mathrm{~h}$ & 1.9 \\
\hline Tile & 1230 & 21.1 & 2045 & 21.9 & 8 h $15 \mathrm{~min}$ & 0.8 \\
\hline
\end{tabular}

${ }^{a}$ Range is the temperature difference between the daily maximum and minimum

b Interval is the duration reckoned from the occurrence of daily minimum to maximum

${ }^{c}$ For the control plot, the surface is the bare tile; for the vegetated plots, the surface is the foliage

$10 \mathrm{~mm}$ of rainfall using an impact type sprinkler. This influence is limited to $\mathrm{L}$ and $\mathrm{M}$ and does not affect $\mathrm{H}$. Its impact is limited to $<1 \mathrm{~h}$ during and soon after irrigation. Once irrigation stops, the cooling effect quickly wanes.

The third feature is that air warming in the morning is delayed at $\mathrm{L}$ and $\mathrm{M}$, with little effect at $\mathrm{H}$. Afternoon cooling at all levels occurs notably earlier than the control. Compared with the control, the grass roof lowers temperature conspicuously both day and night. The maximum temperature reaches $25.3^{\circ} \mathrm{C}$ at $1415 \mathrm{~h}$, which is $1.7^{\circ} \mathrm{C}$ below the control. The minimum temperature drops to $20.6^{\circ} \mathrm{C}$ at $0615 \mathrm{~h}$, which is $0.9^{\circ} \mathrm{C}$ below the control. At all three heights, the occurrence of maximum and minimum temperature is synchronous. It is notable that the maximum occurs on the grass roof about 45 min earlier than on the control roof. Thus, daytime thermal suppression due to latent heat extraction by active evaporation and transpiration from the grass field is more effective than at night (Köhler 2004). Ground cooling by long-wave radiative emission and evaporation at night depresses air temperature near the ground from $\mathrm{L}$ to $\mathrm{M}$ but only slightly for $\mathrm{H}$. The nighttime temperature inversion is steeper than the control. This finding contrasts with the nighttime groundcooling effect of the control site, which without evaporation is unable to suppress near-ground air temperature.

The grass site demonstrates an apparent anomaly in the form of a miniature suspended temperature inversion (STI) from $\mathrm{M}$ to $\mathrm{H}$ during the day. It is characterized by a 
Fig. 5 Diurnal variation of air temperature at three heights above the ground at the control roof site

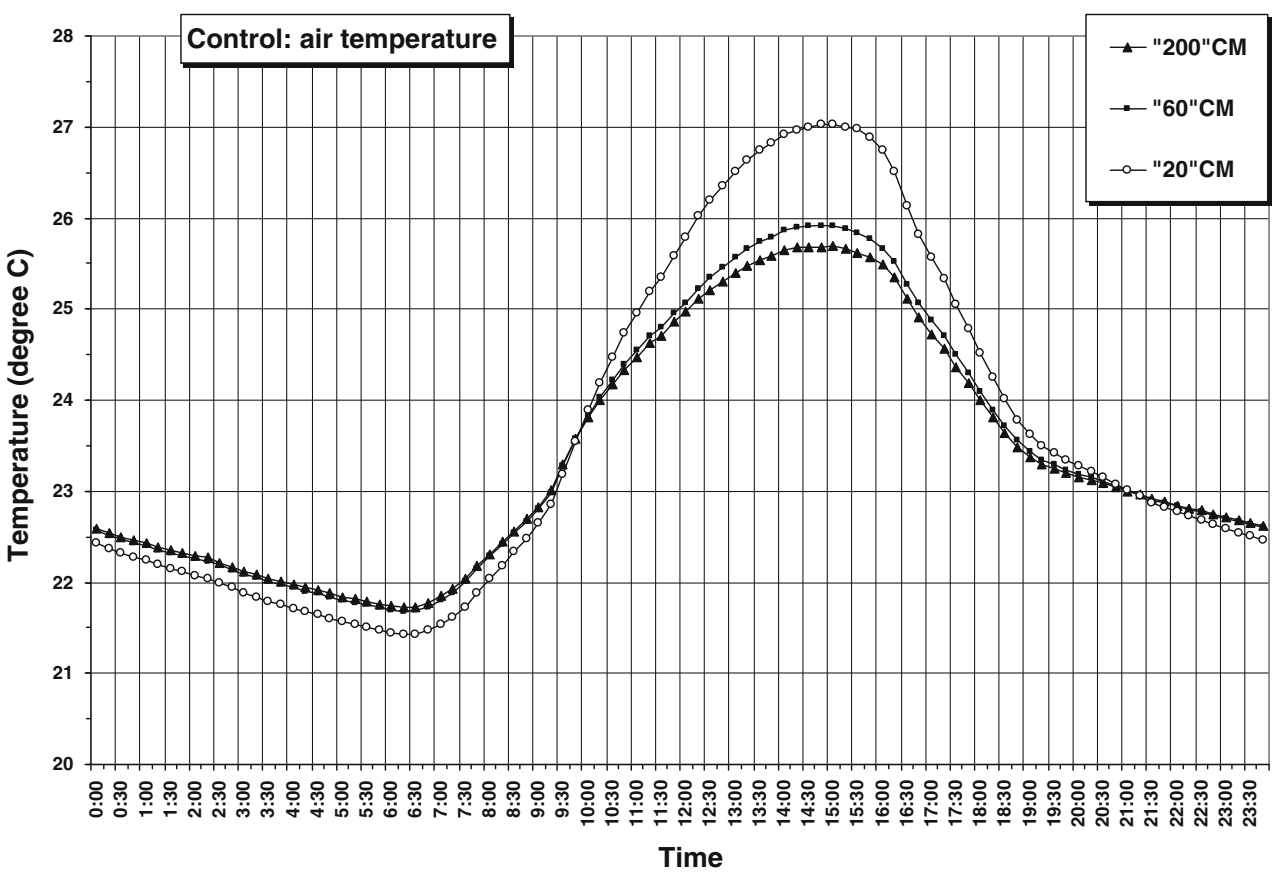

Fig. 6 Diurnal variation of air temperature at three heights above the ground at the greenroof grass site

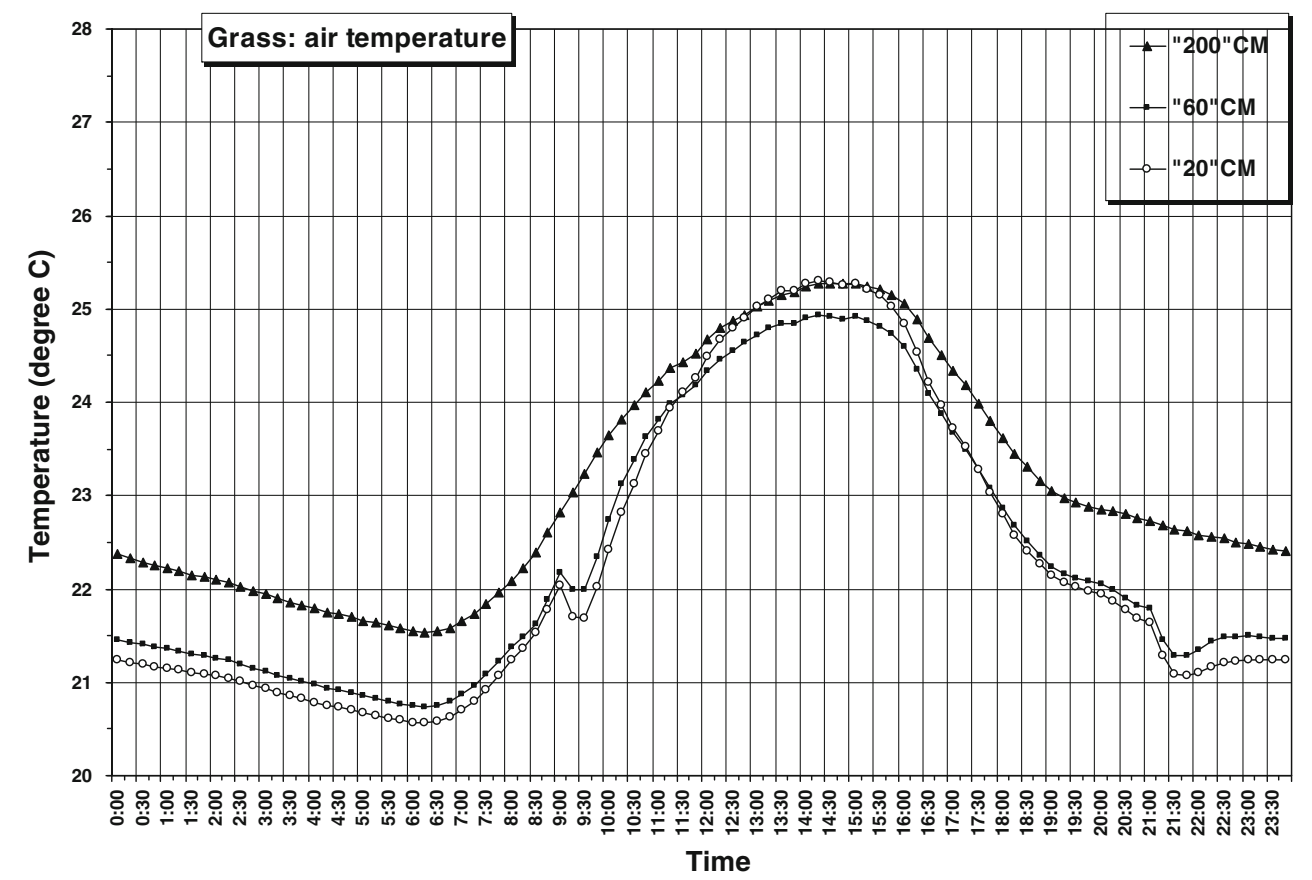

relatively cooler air layer at $\mathrm{M}$ and sandwiched by warmer air at $\mathrm{L}$ and $\mathrm{H}$. The daytime temperature at $\mathrm{L}$ rises above $\mathrm{M}$ from 1200 to $1630 \mathrm{~h}$ and peaks at $1415 \mathrm{~h}$. The pattern is attributed to cosuppression of the $\mathrm{L}$ and $\mathrm{M}$ temperature peaks due to efficient evaporative cooling that extends from the ground upward to M (Pearlmutter and Rosenfeld 2008). Compared with the control, temperature suppression is more pronounced at $\mathrm{L}$ and less so at $\mathrm{M}$. More significantly, the cooling impact pulls the temperature of $\mathrm{M}$ below $\mathrm{H}$ to induce the STI.
Air temperature above the groundcover roof

The air temperature pattern of the herbaceous groundcover vegetation (Fig. 7; Table 3) is similar to the control and different from grass. During the day, the temperature decreases with height, and at night, the temperature inversion sets in. Compared with the control, the temperature is reduced by around $0.5^{\circ} \mathrm{C}$ throughout the 24 -h period.

The groundcover is less effective than grass in cooling itself and the adjacent air. The maximum temperature of 
Fig. 7 Diurnal variation of air temperature at three heights above the ground at the greenroof groundcover site

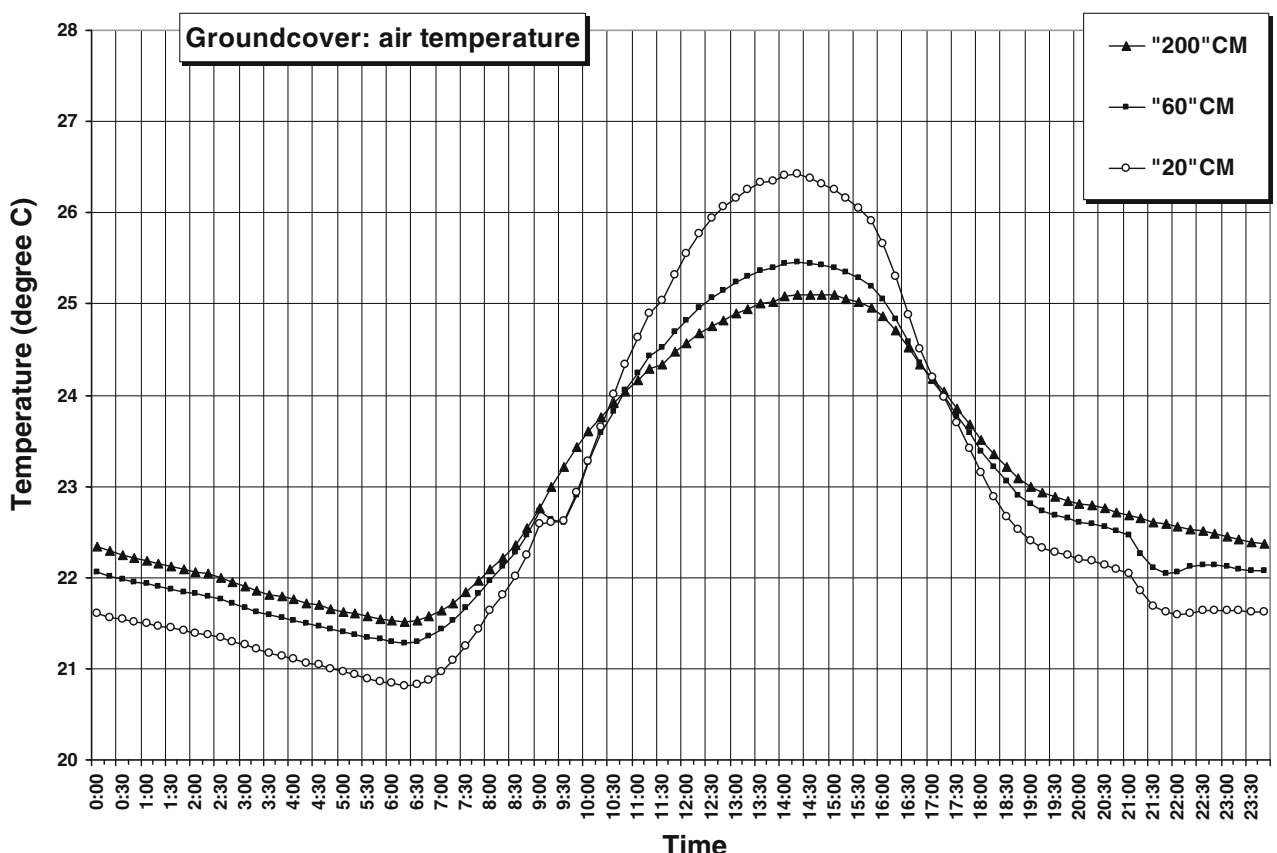

Time $26.5^{\circ} \mathrm{C}$ attained at $1415 \mathrm{~h}$ (same time as grass) is about $1.1^{\circ} \mathrm{C}$ warmer than grass. The minimum temperature of $20.8^{\circ} \mathrm{C}$ occurring at $0630 \mathrm{~h}$ is $0.7^{\circ} \mathrm{C}$ cooler than the control. Moreover, both the warming and cooling rates are faster than grass. Compared with grass, groundcover lowers the maximum daytime temperature at $1415 \mathrm{~h}$ by about $0.6^{\circ} \mathrm{C}$ and the minimum at $0615 \mathrm{~h}$ by $0.5^{\circ} \mathrm{C}$. Similar to the control and contrasting with grass, the widest temperature amplitude occurs during the day. Thus, the daytime temperatureheight gradient is steeper than grass, and the nighttime temperature inversion gradient is gentler than grass. Similar to grass, the maximum temperature occurs about 45 min earlier than the control. The occurrence of the minimum temperature at three heights is synchronous. Different from the control and grass, the timing of maximum temperature shows a small (0.5-h) delay from $\mathrm{M}$ to $\mathrm{H}$. The daytime heating-cooling processes occur later than grass, falling behind slightly in the morning warming and more so in the afternoon cooling. In other words, it takes more time to warm the air and even more to cool it afterward. Compared with the control, the short delay in afternoon cooling is evident.

The perennial herbaceous groundcover forms a dense and multiple-layered mat of living stems resting on the soil to support a surficial layer of foliage. The three-dimensional scaffold framework of living biomass on the soil surface with relatively more tissue moisture content creates a reservoir of thermal capacity. It takes more energy to raise the temperature of the vegetation mat than the simple ground-hugging turfgrass cover. Once warmed, it takes a longer time for groundcover to cool down, suggesting that the vegetation mat is effective in retaining heat. The heat energy stored in the living tissues also pushes the maximum temperature to a relatively high level. The air temperature above the groundcover roof, particularly at $\mathrm{L}$ and to a certain extent at $\mathrm{M}$ and $\mathrm{H}$, is warmed correspondingly.

Air temperature above the shrub roof

The air temperature curves of shrub (Fig. 8; Table 3) deviate markedly from the control, grass, and groundcover. The unusual anomaly is that $\mathrm{M}$ is consistently warmer than $\mathrm{L}$ throughout the 24-h period. The pattern of $\mathrm{H}$ is analogous to the control and groundcover, being warmer than $\mathrm{L}$ and $\mathrm{M}$ at night and cooler during the day. Daytime records show pronounced discrepancies, with the atypical phenomenon of $\mathrm{M}$ warmer than $\mathrm{L}$ and $\mathrm{H}$ for $6 \mathrm{~h}(1045-1645 \mathrm{~h})$ to create a canopy temperature inversion (CTI). In other words, during the day, peak the temperature rises by $0.4^{\circ} \mathrm{C}$ from $\mathrm{L}$ to $\mathrm{M}$ and then drops notably by $0.85^{\circ} \mathrm{C}$ from $\mathrm{M}$ to $\mathrm{H}$. The maximum of $26.2^{\circ} \mathrm{C}$ happens at $1415 \mathrm{~h}$ at $\mathrm{M}$ and the minimum of $20.3^{\circ} \mathrm{C}$ at $0630 \mathrm{~h}$ at $\mathrm{L}$. Of the three vegetated roofs, shrub has the widest temperature amplitude with the highest maximum and lowest minimum. Shrub generates more extremes in diurnal temperature.

The $\mathrm{L}$ and $\mathrm{M}$ air-temperature sensors are located below the top of the shrub canopy $70 \mathrm{~cm}$ above the soil surface. The living biomass of branches and foliage traps air to create its own canopy microclimate. The canopy top is warmed by solar radiation, in turn transferring some heat to the ambient air by convective sensible heat. Heat is dissipated to the air above the canopy. The 
Fig. 8 Diurnal variation of air temperature at three heights above the ground at the greenroof shrub site

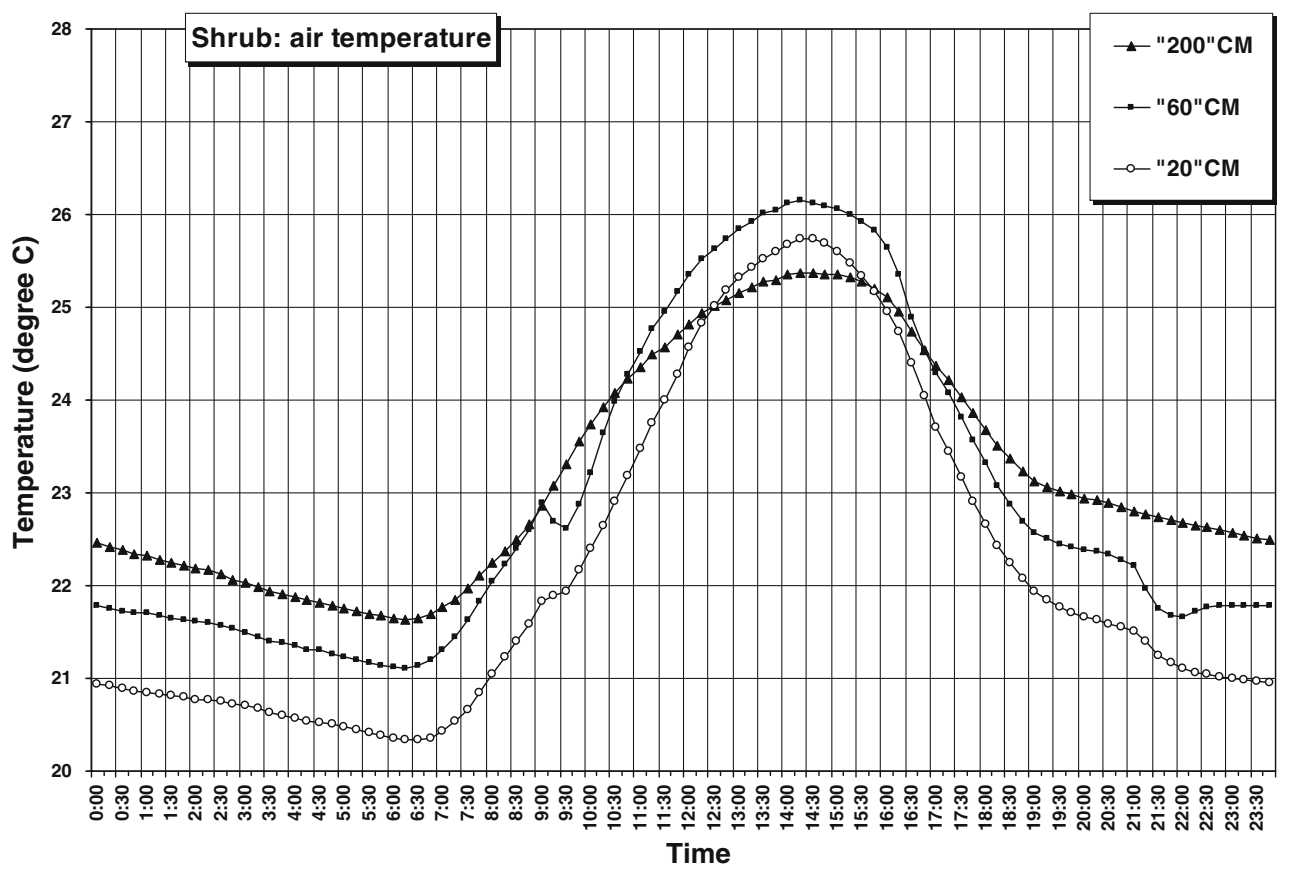

relatively stagnant canopy air, however, serves as a heat sink to accumulate heat energy at $\mathrm{M}$ (just below $60 \mathrm{~cm}$ ). Thus, at $\mathrm{M}$, a relatively high temperature exceeding both $\mathrm{L}$ and $\mathrm{H}$ could be attained to generate CTI. L is cooler than $\mathrm{M}$ during the day by a small margin (about $0.4^{\circ} \mathrm{C}$ ) due to shading from the canopy and the cooling effect of the shaded soil surface. Branch and foliage density drops nearer the soil surface, allowing heat dissipation by air circulation and advection. At $\mathrm{H}$, evapotranspiration exerts its cooling effect on the air lying above the canopy, suppressing the daytime maximum below $\mathrm{L}$ and $\mathrm{M}$. Overall, during the day, the canopy air layer around $\mathrm{M}$ serves as a suspended thermal blanket to insulate the air and soil lying below. At night, the temperature inversion has the steepest gradient of the three vegetated roofs. At midnight, the temperature range between $\mathrm{L}$ and $\mathrm{H}$ reaches $1.6^{\circ} \mathrm{C}$. Except for $3 \mathrm{~h}$ around $1415 \mathrm{~h}, \mathrm{~L}$ remains the coolest of the three heights in the 24-h period. The nighttime $\mathrm{M}$ is the warmest amongst the three vegetated roofs, being on average $0.85^{\circ} \mathrm{C}$ warmer than $\mathrm{L}$ from midnight until dawn. This result indicates that $\mathrm{M}$ continues to retain some heat acquired during the day. At night, the shrub continues to exert its microclimatic influence via radiative and evaporative cooling to drive $\mathrm{L}$ temperature downward. This green-roof effect has a limited vertical range at night, with cooling efficacy progressively declining toward $\mathrm{M}$ and $\mathrm{H}$. This finding suggests that at night, $\mathrm{H}$ is influenced mainly by radiative cooling, whereas $\mathrm{L}$ and $\mathrm{M}$ are cooled additionally by evaporation that continues at night.

\section{Infrared roof-surface temperature}

The four plots show similar surface temperature trends at night from $2300 \mathrm{~h}$ until $0900 \mathrm{~h}$ (Fig. 9). The interplot differences occur mainly during the day. Comparison could be made with reference to daily maximum surface and ambient temperature, timing of their occurrences, and heatgain duration of roof-surface materials. Both control and vegetated plots have maximum surface temperatures consistently higher than adjacent air temperature (Hoyano et al. 1999).

Starting from sunrise, the surface temperature of the control roof (Fig. 9) does not warm above the ambient air (sensor body temperature at $1.5 \mathrm{~m}$ high) until $1030 \mathrm{~h}$. This suggests that the bare tiles have a relatively high thermal capacity to store heat to retard temperature rise. It continues to warm to a maximum of $33.5^{\circ} \mathrm{C}$ at $1430 \mathrm{~h}$. It takes $4 \mathrm{~h}$ of incident solar radiation to heat the roof to the daily maximum temperature. Thereafter, the accumulated heat energy plus the afternoon insolation keep the roof surface warmer than the ambience. After sunset, the residual heat in the tiles continues to keep the roof surface warmer until equilibrium is attained with the ambient air at $2230 \mathrm{~h}$, which is maintained throughout the night. The delayed and extended daily cooling duration presents a notable feature of the bare roof. The area between the two curves, indicating the amount of retained heat energy, denotes that the bare roof material serves as a notable reservoir of heat energy. Overall, the surface temperature profile of the bare roof echoes the urban heat island effect, with excess 
Fig. 9 Diurnal variation of surface temperature of the control plot and three green-roof plots measured by an infrared radiometer compared with the ambient air temperature at $1.5 \mathrm{~m}$ high

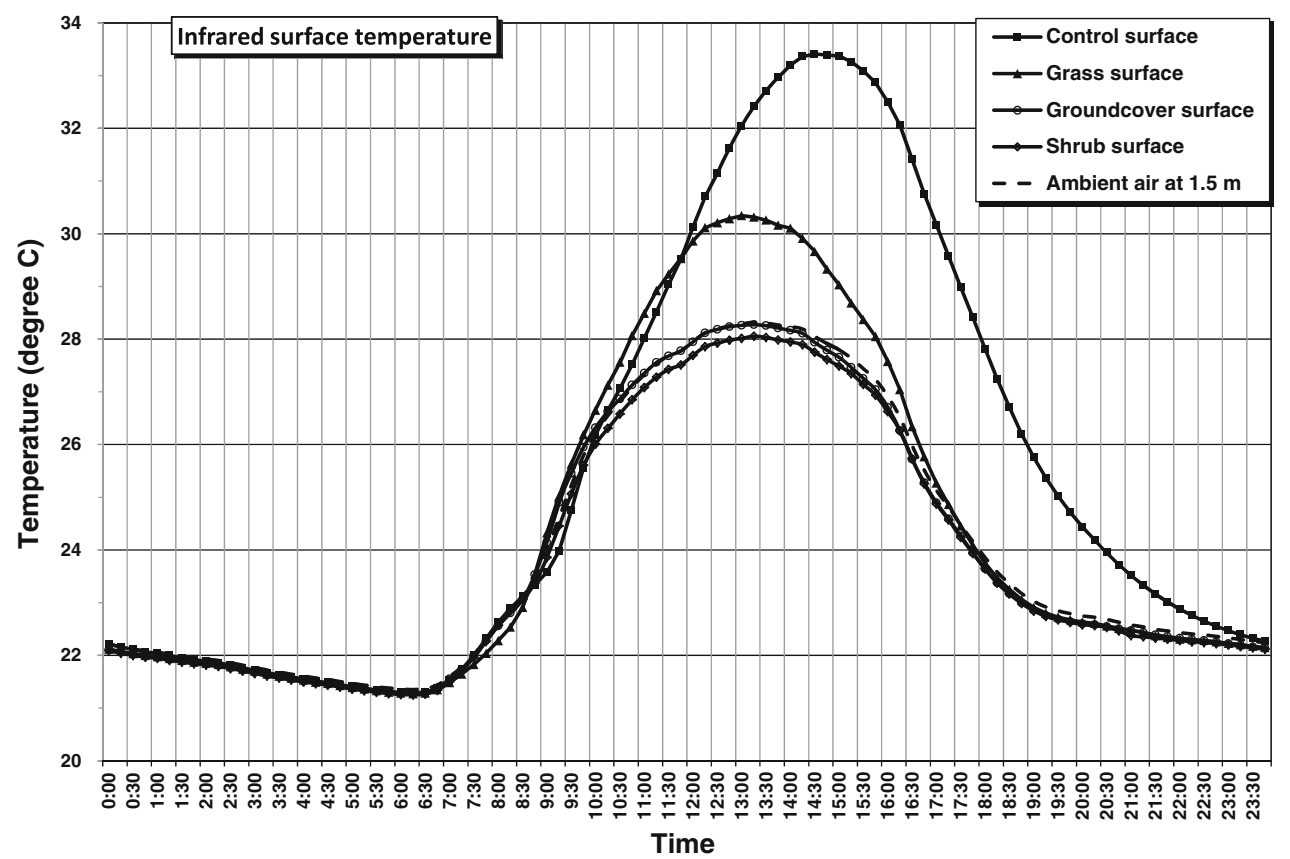

daytime heat absorption and prolonged postsunset release of residual heat to contribute to the hot-night phenomenon.

Of the three vegetated roofs, only the grass surface is warmed to exceed the sensor body temperature (Fig. 9). It attains the daily maximum of $30.2^{\circ} \mathrm{C}$ at $1300 \mathrm{~h}$, which is 1.5-h earlier than the control and about $1^{\circ} \mathrm{C}$ above the sensor body temperature. Whereas evapotranspiration could cool the near-ground air, the effect is insufficient to counteract heating due to intense insolation around noon and in early afternoon. The progressive loss of soil moisture reduces the efficacy of cooling due to latent heat removal. The resultant interactions between heating by insolation and cooling by evapotranspiration are suppression of temperature below the control peak. The limited accumulated heat energy in the grass roof, in conjunction with continual latent heat withdrawal, could not sustain the elevated surface temperature for long. As early as $1700 \mathrm{~h}$, equilibrium with the ambience is attained, which is thereafter maintained until the next morning. Overall, the grass surface experiences a limited warming episode to attain an early but moderate maximum temperature and retains a limited amount of heat energy, which is dissipated rather quickly in the late afternoon.

Groundcover and shrub roofs have similar surface thermal performance (Fig. 9). Vegetation surface and the sensor body have nearly the same temperature throughout the $24-\mathrm{h}$ period. The maximum temperature of $28.1^{\circ} \mathrm{C}$ is achieved at $1315 \mathrm{~h}$, which is $1.25 \mathrm{~h}$ earlier than the control. Groundcover warms up earlier and cools down earlier than shrub by about $0.5 \mathrm{~h}$. The effective evapotranspirational cooling could hold the surface temperature down (Wong et al. 2007). It also indicates that the vegetation canopy of groundcover and shrub are rather divorced from the substrate due to the presence of an intervening air gap between the soil surface and the stem-foliage stratum. This physical separation creates a perched thermal discontinuity (PTD) to delink the stem-foliage temperature regime from the substrate. Thus, the stem-foliage stratum is literally lifted above the soil and exposed to the air to allow thermal equilibrium with the ambient air throughout the 24-h cycle.

\section{Subsurface-material temperature of vegetated roofs}

The material temperature of the three vegetated roofs, including the bottom tile, the middle rockwool, and the top soil layers show markedly different diurnal temperature patterns (Figs. 10, 11, 12; Table 3). During the day, the three plots demonstrate the same temperature trend of soil $>$ rockwool $>$ tile, indicating evident solar heat gain from above and heat dissipation and temperature decline with depth (Teemusk and Mander 2010). The magnitude of the decrease, however, varies greatly by vegetation type. Grass registers a significantly higher maximum soil temperature at $30.9^{\circ} \mathrm{C}$ compared with $24.9^{\circ} \mathrm{C}$ for groundcover and $23.8^{\circ} \mathrm{C}$ for shrub. In comparison, the bare roof reaches a maximum temperature of $33.4^{\circ} \mathrm{C}$, indicating notable cooling of the soil by the combined effect of vegetation shading (D’Orazio et al. 1998; Kumar and Kaushik 2005) and evapotranspiration. To be effective, the soil should remain moist to sustain the latent heat-dissipation process (Lazzarin et al. 2005). The maximum rockwool temperature of grass is also higher than groundcover and shrub. The temperature difference between vegetation types declines with depth. At the tile layer, grass and groundcover remain rather cool, with 
Fig. 10 Diurnal variation of material temperature in the soil, rockwool, and tile layers at the green-roof grass site
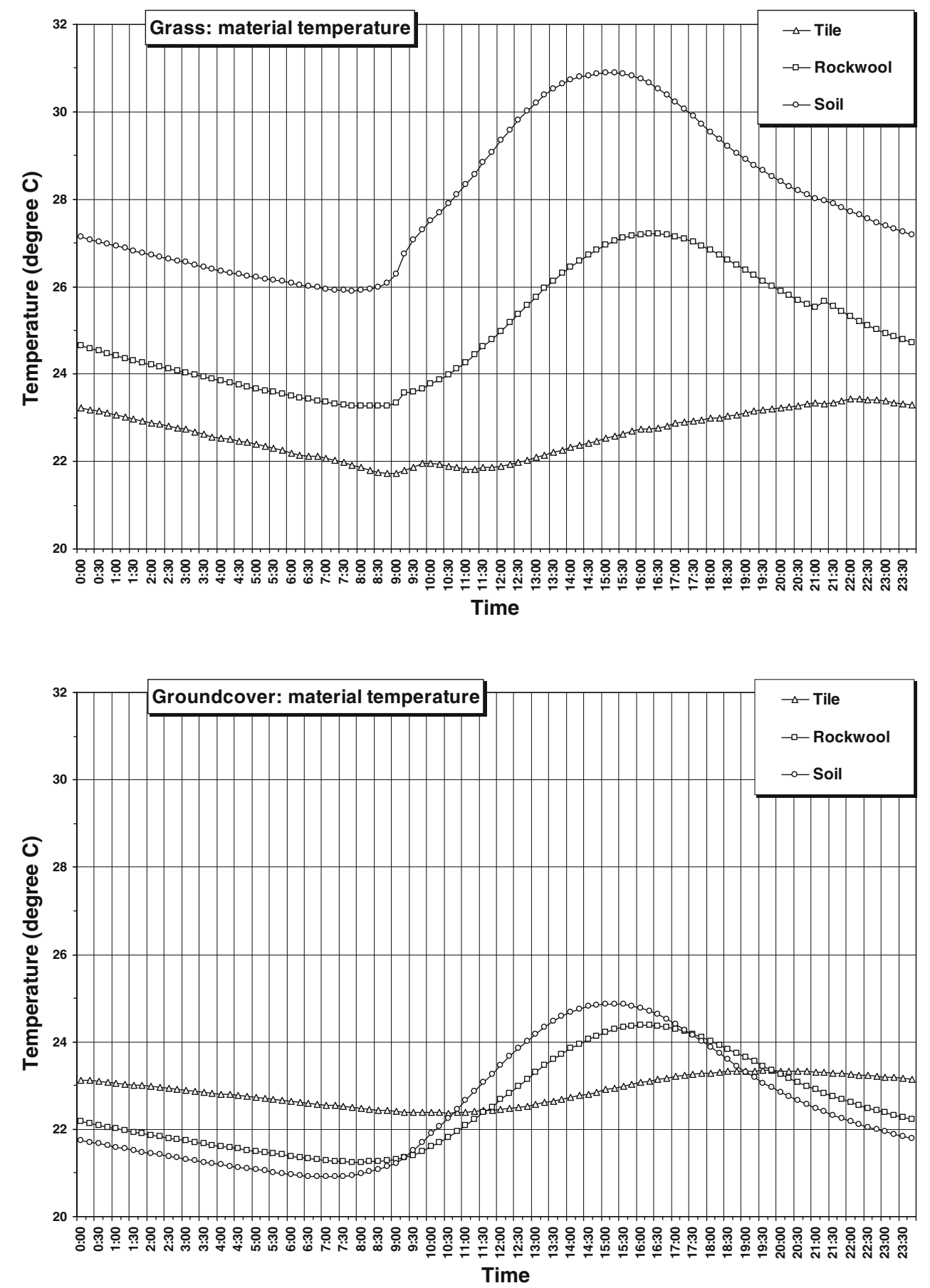

Fig. 11 Diurnal variation of material temperature in the soil, rockwool, and tile layers at the green-roof groundcover site similar temperatures (respectively, 23.5 and $23.2^{\circ} \mathrm{C}$ ), whereas shrub is slightly lower $\left(21.9^{\circ} \mathrm{C}\right)$.

Groundcover and shrub, with more biomass and soil thickness, are more efficient in shielding and cooling the soil than is grass. The presence of an air gap between the main foliage (transpirational) layer and soil in groundcover, and more so in shrub, plays a pertinent role in reducing heat gain by the soil. The contiguity of grass and soil does not create a comparable insulating air gap. The moisture held in the soil and rockwool layers serves as a thermal reservoir to store and to transmit heat. The water can facilitate heat transfer from soil to rockwool, as indicating by the heated grass soil, which passes its heat to rockwool with the help of moisture.

At night, the minimum soil and rockwool temperatures of grass are higher than groundcover and shrub. The minimum tile temperatures for the three vegetation types $\left(21.1-22.2^{\circ} \mathrm{C}\right)$ are comparable and similar to the minimum 
Fig. 12 Diurnal variation of material temperature in the soil, rockwool, and tile layers at the green-roof shrub site

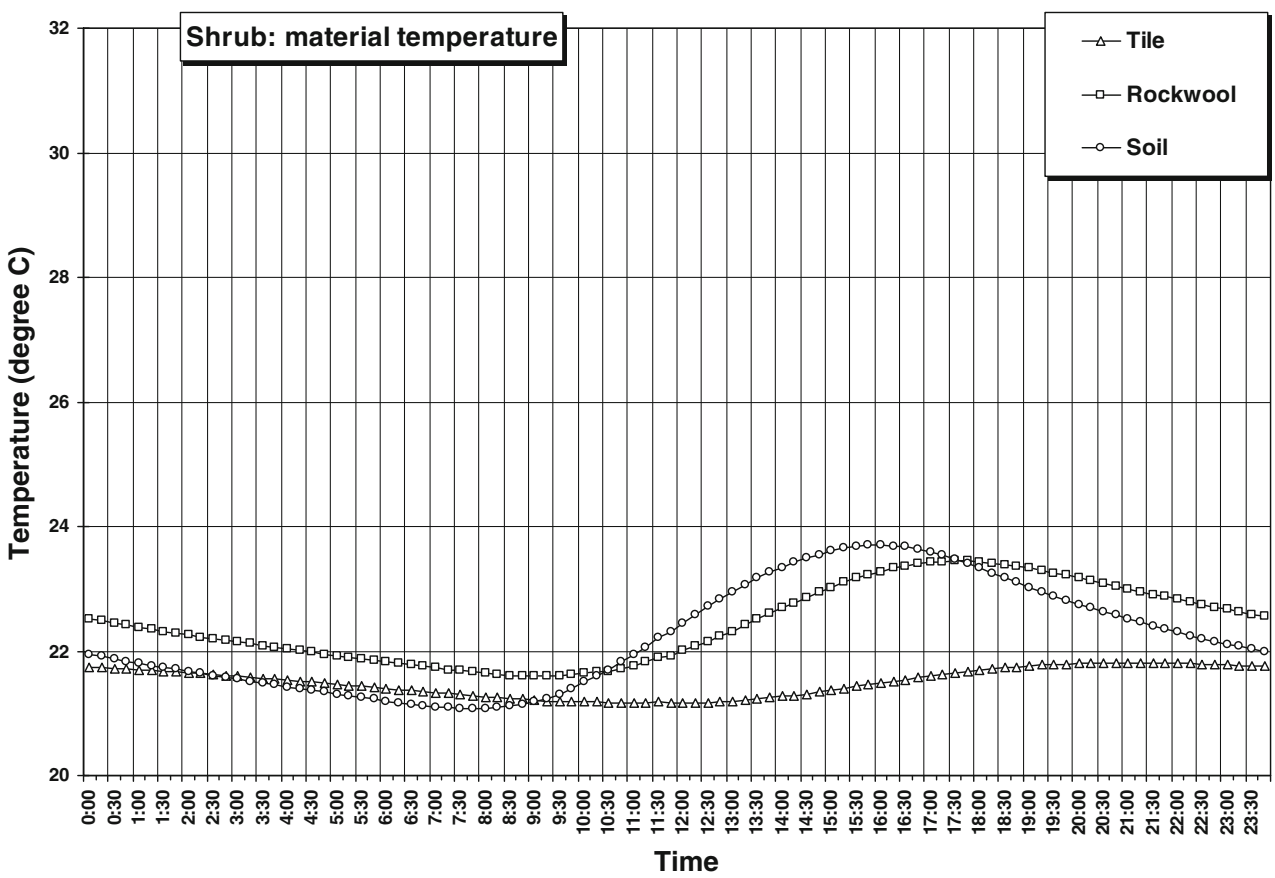

recorded by the bare control surface $\left(21.3^{\circ} \mathrm{C}\right)$. Grass maintains the depth-decline temperature pattern throughout the night. Groundcover shows a reverse trend, equivalent to a temperature inversion, with cooler soil and progressively warmer rockwool and tile temperatures. Shrub demonstrates an anomalous sandwich scenario, with a slightly warmer rockwool layer wrapped by cooler soil above and cooler tile below. The radiative and limited evaporative cooling help to lower the nighttime soil temperature, but the effect could not reach the buried rockwool. The tile temperature was not cooled at night but, rather, is barely warmed during the day and remains cool throughout the diurnal cycle.

The diurnal temperature range decreases with depth, with soil the widest followed by rockwool and tile. Soil and rockwool temperatures display an early afternoon peak with the characteristic bell-shaped curve, but this pattern is absent in the tile-temperature data. The intervening plastic drainage layer, filled by air most of the time (except during very heavy rainfall), serves as an excellent thermal insulation medium. The diurnal tile temperature fluctuation is pronouncedly suppressed to $1.7^{\circ} \mathrm{C}$ in grass and down to merely $1.0^{\circ} \mathrm{C}$ in groundcover and $0.8^{\circ} \mathrm{C}$ in shrub. The above-ground biomass of vegetation, particularly density, height, and leaf-area index (LAI), plays a key role in dampening the tile temperature (Takakura et al. 2000). Shrub has a three-dimension biomass structure that traps air and elevates the transpirational surfaces above the ground, with a relatively high LAI, and has the most effective passive substrate cooling. The thicker soil of the shrub plot plays a role in the cooling process (Wong et al. 2002; Liu and Bass 2005).

A combination of thermal insulation and evaporative cooling helps reduce heat gain at the bottom of the green roofs. The limited variations in diurnal tile temperature reflect the significant effect of the green roofs in suppressing heat transmission through the roof concrete slab and hence the indoor space underneath. Heat could transmit effectively from surface to soil and from soil to rockwool with the help of soil moisture. The passage of heat from rockwool to tile, however, is evidently arrested. The drainage layer, a $25-\mathrm{mm}$ plastic sheet that contains air most of the time, plays a crucial insulation role in the form or an air gap between the rookwool and the tile. It presents a collateral benefit, a subsurface thermal discontinuity (STD), that hitherto has not been noted or assessed in green-roof studies. The root-barrier layer also contributes in a limited way to the overall insulation effect of the green-roof materials (Del Barrio 1998; Theodosiou 2003). Thus, vegetated roofs can reduce heat gain in indoor spaces in summer and correspondingly reduce air-conditioning energy consumption (Onmura et al. 2001; Santamouris et al. 2007; Spolek 2008). It can also extend the life span of the waterproofing layer (Liu and Baskaran 2003; Teemusk and Mander 2009). The economic benefits of electricity saving and less frequent refurbishment of the waterproofing layer could offset the capital and maintenance costs of green roofs. 
Comparison with temperature profile on a typical summer day

Figure 4 shows the diurnal variation in air, infrared surface, and soil temperature on a typical summer day. It can be compared with the trends obtained by the composite average approach adopted in the study. The air temperature at $200 \mathrm{~cm}$ high (Fig. 4a) shows a hotter control, especially from midday to around $1750 \mathrm{~h}$. The air above the three vegetated surfaces has similar temperature throughout the day. A comparable trend is observed in the composite results (Figs. 5, 6, 7, 8). The differential effect of the three vegetation types on air temperature is, however, vividly displayed at the $20-\mathrm{cm}$ level (Fig. 4b). The more significant cooling benefit of shrub with a taller, denser, and more elaborate biomass structure is evident. Grass with the simplest and least biomass can warm the near-ground air more than the control for some episodes in the morning and early afternoon. This short-term phenomenon is not picked up by the composite results, suggesting the occurrence of an extreme event during the occasional very hot summer days. The small-scale ups and downs in the daytime temperature curves in summer, particularly in the afternoon, are suppressed by the composite values.

For the infrared surface temperature (Fig. 4c), the confluence of the four curves at night after a period of cooling, mainly from 2200 to $1000 \mathrm{~h}$ next morning, is similarly according to the two data sets (Figs. 4, 9). The pronounced divergence that begins to emerge especially after midday, with control and grass quickly gaining heat to create a sharp increase in temperature above groundcover and shrub, also displays a striking resemblance. As with the 20-cm air-temperature trends, the infrared surface temperature also demonstrates ups and downs that correspond to short-term weather changes, such as temporary cloud cover. Such short-duration fluctuations are submerged by the composite data transformation.

The soil temperature graph (Fig. 4d) indicates accumulation of solar heat in the substrate after sunrise, gradually raising soil temperature to the maximum at around 1430-1500 h. During the night, the radiative cooling patterns of the two data sets are also very similar, with a tendency to reach a minimum at early morning at round $0700-0800 \mathrm{~h}$. The grass-soil temperature is significantly higher than that of groundcover, which is similar to shrub, throughout the entire day. In the overall 24-h cycle, the relativity in soil temperature, with grass $\gg$ groundcover $>$ shrub, matches the trend in the composite results (Figs. 10, 11, 12). Compared with air and surface temperature data, the soil material has an evident dampening effect on short-term fluctuations, as indicated by the notably more smooth curves.
The main limitation of the composite average approach is that some of the extreme daily conditions could be masked by the overall summary. The composite computation is analogous to deriving a running average through the time dimension. The small-scale variations through time, especially in relation to short-term events, are smoothed by the numerical treatment. Days with exceptionally high or low or wide or narrow diurnal range in temperature could not be highlighted. Days with unusual weather conditions, such as prolonged heavy rains, overcast sky, and hot and cold spells, would not be indicated as individual events. The seasonal variations could also be drawn toward the main trends of the aggregated data.

\section{Conclusion}

Few studies have evaluated the passive cooling effect of a green roof in relation to vegetation growth form, which varies by plant height and biomass quantity and density. This study contributes to the understanding of the differential impacts of three vegetation types on air, surface, and substrate temperatures at seven levels in a humid, tropical environment. The main temperature variations occur during the day, with similar cooling trends at night. Vegetated roofs register suppression of diurnal minimum and maximum air temperature but limited reduction in diurnal temperature range. The vegetated roofs do not cool air more than the control at night. Grass demonstrates more air cooling than groundcover and shrub. During the day, grass develops a miniature suspended temperature inversion (STI) and shrub develops a canopy temperature inversion (CTI).

The thermal performance of the three vegetation types demonstrates pronounced variations in air temperatures at different heights, surface temperature, and material temperature at different depths. The findings indicate the key role played by biomass quantity and structural complexity in molding the passive cooling functions. Shrub has the densest and most complex biomass structure. Contrary to common belief, it creates the most extreme diurnal air temperature regime. Grass has the simplest biomass structure but it is more able to create passive air cooling. Groundcover and shrub, with a concentration of transpirational foliage elevated above the soil, create passive cooling, by perched thermal discontinuity (PTD). The air gap of the plastic drainage layer arrested downward heat transmission in all vegetated plots to form a subsurface thermal discontinuity (STD).

The notable differences in temperature among vegetation types, however, tend to be accentuated in the surface and substrate layers, and they decline notably with depth. The grass plot has notably warmer soil and rockwool layers 
than the groundcover and shrub plots. At the bottom of the green roofs, the tile temperature of grass, groundcover, and shrub converge to a common low level. Little heat moves from soil and rockwool layers to the tile, indicating the effective insulation provided by the drainage layer. Thus, a relatively thick drainage layer brings dual benefits: quickly shedding water from heavy tropical rain storms and providing a subsurface thermal discontinuity. A green roof with a continuous and vigorous vegetation cover is more important than vegetation type in reducing heat gain into buildings. This finding corroborates with that obtained in a focused study of the cooling effect of the abiotic layers in green roofs (Jim and Tsang 2011). This finding has important implications to the choice of green-roof materials and vegetation in the humid tropics.

The near-ground air and surface temperatures experienced by green-roof users have key implications on human comfort and overall urban heat-island suppression (Smith and Levermore 2008). The natural passive-cooling effect of green roofs could play a useful role in ameliorating urban heat stresses and providing the collateral ecological and amenity benefits. Both daytime and nighttime urban heat island effect could be ameliorated by irrigated green roofs. The research also verifies the applicability of a light-weight extensive green-roof system in humid, tropical conditions. The findings could provide an alternative dimension to the choice of vegetation and system design for roof greening in tropical cities as a part of the bioclimatic building design, making use of natural and sustainable cooling features (Hatamipour and Abedi 2008).

Acknowledgments I acknowledge with gratitude the grants kindly awarded by the Midland Charitable Foundation and the Stanley Ho Alumni Challenge Fund, and the green-roof donation by Cheung Shing Yuk Tong Limited. The field-work assistance provided by Jeannette Liu and W.Y. Wong is warmly appreciated.

Open Access This article is distributed under the terms of the Creative Commons Attribution Noncommercial License which permits any noncommercial use, distribution, and reproduction in any medium, provided the original author(s) and source are credited.

\section{References}

Akbari H, Konopaci S (2005) Calculating energy-saving potentials of heat-island reduction strategies. Energy Policy 33:721-756

Banting D, Doshi H, Li J, Missios P (2005) Report on the environmental benefits and costs of green roof technology for the City of Toronto. Ontario Centre of Earth and Environmental Technologies, Ontario, Canada, $65 \mathrm{p}$

Bass B, Krayenhoff S, Martilli A, Stull R (2002) Mitigating the urban heat island with green roof infrastructure. In: Urban heat island summit: mitigation of and adaptation to extreme summer heat, 1-4 May 2002, Toronto, $10 \mathrm{p}$

Bass B, Krayenhoff ES, Martilli A, Stull RB, Auld H (2003) The impact of green roofs on Toronto's urban heat island. In:
Conference on greening rooftops for sustainable communities, 29-30 May 2003, Chicago, 13 p

Chang CR, Li MH, Chang SD (2007) A preliminary study on the local cool-island intensity of Taipei city parks. Landsc Urban Plan 80:386-395

D’Orazio MC, Cianfrini C, Corcione M (1998) Effects of vegetation roof shielding on indoor temperatures. Int $\mathrm{J}$ Heat Technol 16:85-90

Del Barrio EP (1998) Analysis of the green roofs cooling potential in buildings. Energy Build 27:179-193

EPA (2009a) Reducing urban heat islands: compendium of strategies, heat island reduction activities. Environmental Protection Agency, Washington, DC, $20 \mathrm{p}$

EPA (2009b) Reducing urban heat islands: compendium of strategies, green roofs. Environmental Protection Agency, Washington, DC, $26 \mathrm{p}$

Hatamipour MS, Abedi A (2008) Passive cooling systems in buildings: some useful experiences from ancient architecture for natural cooling in a hot and humid region. Energy Convers Manag 49:2317-2323

Hong Kong Observatory (2005) Summary of meteorological observations in Hong Kong 2004. Hong Kong Government, Hong Kong, $87 \mathrm{p}$

Hoyano A, Asano K, Kanamaru T (1999) Analysis of the sensible heat flux from the exterior surface of buildings using time sequential thermography. Atmos Environ 33:3941-3951

Jim CY (2008) Ecological design of sky woodland in compact urban Hong Kong. In: Greening rooftops for sustainable communities, Green Roofs for Healthy Cities, Baltimore, p 15

Jim CY, Tsang SW (2011) Modeling the heat diffusion process in the abiotic layers of green roofs. Energy Build 43(6):1341-1350

Köhler M (2004) Energetic effects of green roofs to the urban climate near to the ground and to the building surfaces. In: International green roof congress, 14-15 September 2004, Nürtingen, Germany, pp 72-79

Kumar R, Kaushik SC (2005) Performance evaluation of green roof and shading for thermal protection of buildings. Build Environ 40:1505-1511

Lazzarin RM, Castellotti F, Busato F (2005) Experimental measurements and numerical modeling of a green roof. Energy Build 37:1260-1267

Lee S-H, Lee K-S, Jin W-C, Song H-K (2009) Effect of an urban park on air temperature differences in a central business district area. Landsc Ecol Eng 5:183-191

Liu K (2003) Engineering performance of rooftop gardens through field evaluation. NRCC-46294, National Research Council, Institute for Research in Construction, Ottawa, Ontario, $15 \mathrm{p}$

Liu K, Baskaran B (2003) Thermal performance of green roofs through field evaluation. NRCC-46412, National Research Council, Institute for Research in Construction, Ottawa, Ontario, Canada, $10 \mathrm{p}$

Liu K, Bass B (2005) Performance of green roof systems. NRCC47705, National Research Council, Institute for Research in Construction, Ottawa, Ontario, $18 \mathrm{p}$

$\mathrm{Ng}$ E, Yuan C, Chen L, Ren C, Fung JCH (2011) Improving the wind environment in high-density cities by understanding urban morphology and surface roughness: a study in Hong Kong. Landsc Urban Plan 101:59-74

Onmura S, Matsumoto M, Hokoi S (2001) Study on evaporative cooling effect of roof lawn gardens. Energy Build 33:653-666

Pearlmutter D, Rosenfeld S (2008) Performance analysis of a simple roof cooling system with irrigated soil and two shading alternatives. Energy Build 40:85-864

Sailor DJ (2006) Mitigation of urban heat islands: recent progress and future prospects. Paper presented on american meteorological society 6th symposium on the urban environment and forum on 
managing our physical and natural resources, January 2006, Atlanta

Santamouris M, Pavlou C, Doukas P, Mihalakakou G, Synnefa A, Hatzibiros A, Patargias P (2007) Investigating and analysing the energy and environmental performance of an experimental green roof system installed in a nursery school building in Athens, Greece. Energy 32:1781-1788

Shin DH, Lee KS (2005) Use of remote sensing and geographical information systems to estimate green space surface-temperature change as a result of urban expansion. Landsc Ecol Eng 1:169-176

Smith C, Levermore G (2008) Designing urban spaces and buildings to improve sustainability and quality of life in a warmer world. Energy Policy 36:4558-4562

Spolek G (2008) Performance monitoring of three ecoroofs in Portland, Oregon. Urban Ecosyst 11:349-359

Taha H, Akbari H, Rosenfeld A (1991) Heat island and oasis effects of vegetative canopies: micro-meteorological field-measurements. Theor Appl Climatol 44:123-138

Takakura T, Kitade S, Goto E (2000) Cooling effect of greenery cover over a building. Energy Build 31:1-6
Teemusk A, Mander Ü (2009) Greenroof potential to reduce temperature fluctuations of a roof membrane: a case study from Estonia. Build Environ 44:643-650

Teemusk A, Mander Ü (2010) Temperature regime of planted roofs compared with conventional roofing systems. Ecol Eng 36:91-95

Theodosiou TG (2003) Summer period analysis of the performance of a planted roof as a passive cooling technique. Energy Build 35:909-917

Wong NH, Wong VL, Chen Y, Lee SE, Cheong D, Lim GT, Ong CL, Sia A (2002) The thermal effects of plants on buildings. Arch Sci Rev 45:337-348

Wong NH, Chen Y, Ong CL, Sia A (2003) Investigation of thermal benefits of rooftop garden in the tropical environment. Build Environ 38:261-270

Wong NH, Tan PY, Chen Y (2007) Study of thermal performance of extensive rooftop greenery systems in the tropical climate. Build Environ 42:25-54

Yokohari M, Amati M (2005) Nature in the city, city in the nature: case studies of the restoration of urban nature in Tokyo, Japan and Toronto, Canada. Landsc Ecol Eng 1:53-59 